University of Nebraska - Lincoln

DigitalCommons@University of Nebraska - Lincoln

Faculty Publications in Educational

Administration

Educational Administration, Department of

$12-2016$

\title{
Leadership Development for School Principals: An Adult Learning Perspective
}

Hyun-Jun Joo

Taeyeon Kim

Follow this and additional works at: https://digitalcommons.unl.edu/cehsedadfacpub

Part of the Educational Administration and Supervision Commons

This Article is brought to you for free and open access by the Educational Administration, Department of at DigitalCommons@University of Nebraska - Lincoln. It has been accepted for inclusion in Faculty Publications in Educational Administration by an authorized administrator of DigitalCommons@University of Nebraska - Lincoln. 


\title{
Journal of Educational Administration and Policy
}

\section{Leadership Development for School Principals: An Adult Learning Perspective}

\author{
Joo, Hyun-Jun ${ }^{\mathrm{a}} \cdot$ Kim, Taeyeon ${ }^{\mathrm{b}}$ \\ ${ }^{a}$ Daegu National University of Education \\ ${ }^{b}$ Michigan State University
}

\section{A B S T R A C T}

\begin{abstract}
Although research has increasingly recognized the importance of principal leadership development for school reform, both the content and delivery system continues to be open to debate. In this paper, we review school principal leadership development and provide a conceptual framework for developing school principal leadership based on adult learning theories. We conceptualize school principals as adult educators and adult learners based on key assumptions of adult learning theories. School principals are understood as both adult educators and adult learners in that they need to develop their leadership as well as support teachers' learning in the context of professional development. Relying on these assumptions, we draw philosophical foundations and directions for principal leadership development programs. We attest that constructivism, humanism, and critical social theory can philosophically support principal leadership development, and that leadership programs need to promote knowledgeable, practice, and reflexive leadership.
\end{abstract}

Keywords: principal leadership, adult learning, leadership development

\section{I . Introduction}

School principal leadership has been underscored as a crucial theme in school improvement and educational reform movements (Desjardins \& Donaldson, 2008; Drago-Severson \& Pinto, 2009; Leithwood, Seashore Louis, Anderson, \& Wahlstrom, 2004). Over the past two decades, researchers have demonstrated that school principals directly affect teachers' motivation and school culture; through these effects, research on school

* This paper has been supported by research funding from Daegu National University of Education in 2016.

$\uparrow$ Corresponding Author: Taeyeon Kim

Department of Educational Administration, Room 140 Erickson Hall, Michigan State University, East Lansing, MI 48824-1034.

E-mail: kimtaeye@msu.edu effectiveness has revealed that school principal leadership is one of the most significant factors in student achievement (Liu, Hallinger, \& Feng, 2016; Murphy, 1990).

There is a considerable diversity in the scale, nature, and impact of the leadership preparation and development models used in different countries (Bush, 2013). However, there have been few arguments based on the importance of context in shaping principal leadership. Recently, researchers have noted that adult learning theories can offer useful frameworks to support principal leadership development (Kegan \& Lahey, 2009; Drago-Severson, 2009, 2012). In considering leadership development as work place learning, school principals can be understood as adult learners, as their learning relies on the fundamental assumptions of Andragogy: adult learners tend to focus on self-motivated learning, experience-based learning, developmental-task-based learning, problem oriented 
learning, and intrinsically motivated learning (Merriam \& Bierema, 2014). It is necessary to consider school principals as adult learners in that they have their own goals and motivations in continuing their ongoing leadership development.

Adult learning theories have been applied to leadership development in different areas, including leadership in private and public institutions. In regards to teacher education and training programs, several researchers suggest using frameworks based on adult learning. Adult learning theories differentiate adult learners from child learners in terms of their needs, motivations, learning processes, and learning contexts (Merriam \& Bierema, 2014). As such, principal leadership development can be considered with a lens of transformative learning, which has become a dominant theory in adult learning during the last three decades (Cranton \& Taylor, 2012). Unlike informational learning, which focuses on acquiring knowledge and skills, transformative learning involves "the development of the cognitive, emotional, interpersonal, and intrapersonal capacities that enable a person to manage complexity of work" (Drago-Severson, 2009, p. 11). Through transformative learning, learners can experience qualitative shifts in their ways of assuming, analyzing, understanding, and interpreting their experiences and contexts (Mezirow, 2012). Therefore, it can be said that outcomes of transformative learning are directly connected to actual changes in action, both at individual and organizational levels. In this way, transformative learning supports leaders' capacities to make authentic changes in themselves and their organizational lives.

School principals are regarded as adult educators in that they need to facilitate learning and development of teachers in the context of professional development (Drago-Severson, 2012). For school principals, learning and educating cannot be separated from their leadership development, as they occur simultaneously. School leaders are adults and senior professionals, who expect to be involved in determining their own leadership learning (Bush, 2013). School principals are responsible for developing leadership for themselves as well as teachers and staffs in their schools. For this reason, principals are identified as adult learners, as well as adult educators. As life-long learning is required in the current, complicated school environment, principals need to make progress in their leadership growth to solve problems and make the right decisions. Through the analysis and interpretation of their professional experiences, school principals can attain new skills and improve knowledge to achieve their specific goals.

State, national, and international investments in the pre-service and in-service training of principals have increased dramatically over several decades (Hallinger, 1992; Murphy, 1990; Yilimaki \& Jacobson, 2013). For example, the Korean government has undertaken several institutional efforts focused on higher education since the early1960s, a master's program for educational administration and a national education training institute (Cho \& Joo, 2009). As understandings of principal leadership began to deepen, increased attention was devoted to the training of school leaders, including preparatory training, certification, master's degrees, and ongoing development programs. A great deal of effort has been poured into attempts to rebuild and redesign principal leadership training programs. Although academic scholars and educational practitioners have been engaged in the work of developing leadership programs, understanding of the leadership development of school principals is still limited and unclear. For example, researchers have criticized existing principal leadership preparation movements as being reliant on one-dimensional learning approaches. Therefore, there are gaps between leadership programs and principals' practices in actual leadership situations (Jin, Lee, Kim, \& Yu, 2003). In addition, principal leadership programs are limited in providing opportunities to reflect on their experiences and decision making practices (Donaldson, 2008).

As noted above, while it is important to conceptualize principal leadership development via the notion of principals as adult educators and adult learners, there have been few approaches designed to specifically analyze leadership development through the perspective of adult learning. The purpose of this study is to provide a conceptual framework for school principal leadership development that relies on adult learning theories. The authors examine adult learning theories as theoretical backgrounds and conceptualize school principals as both adult educators and adult learners. Based on this examination, the authors create a conceptual model for principal leadership development programs in order to support successful leadership in todays' schooling. 


\section{Adult Learning Theories}

This section provides understanding of adult learning theories as a theoretical framework. We explore Andragogy and self-directed learning as an early foundational work. Then, we examine transformative learning theories, which has been dominant in adult learning during the last three decades (Cranton \& Taylor, 2012), especially focusing on Mezirow's transformative learning theory.

\section{A. Foundational Adult Learning Theories}

The first systemically formed learning theory for adult learning, Andragogy, was promoted by Knowles in the 1970s (Merriam \& Bierema, 2014; Savicevic, 2008). By distinguishing adult education from childhood education, Andragogy has contributed to professionally establishing knowledge about adult learners (Merriam \& Bierema, 2014). Knowles (1980) initially provided four assumptions about adult learners: (a) adults have a self-concept of autonomy and are self-directed, (b) learners use accumulated experience as a resource for learning, (c) the developmental tasks of adult learners' social roles affect the readiness of learning, and (d) adult learning is more problem centered than subject centered. In his later publications (Knowles, 1984; Knowles \& Associates, 1984), Knowles added two more assumptions for adult learners: (e) adult learners are mainly driven by internal motivations and (f) adult learners want to know the reasons for learning something.

The other theory influential to adult learning is self-directed learning. Self-directed learning suggests that the learner takes control of his or her own learning, which means the learner decides what and how to learn. Self-directed learning has been defined as both a personal attribute - a self-directed learner who is very autonomous, is comfortable with autonomy, and prefers to learn in a self-directed way ${ }^{-}$and a process of learning $-\mathrm{a}$ learner-controlled approach to learning (Merriam \& Bierema, 2014). Knowles (1975) explained the process of self-directed learning as "individuals take the initiative, with or without help from others, in diagnosing their learning needs, formulating learning goals, identifying human and material resources for learning, choosing and implementing appropriate learning strategies, and evaluating those learning outcomes" (p. 18). Relying on the notion that adult learners are more self-motivated and independent, self-directed learning aims to inspire learners to gain knowledge or develop skills and to be self-directed in learning in order to inspire transformational learning (Merriam \& Bierema, 2014).

Based on these fundamental assumptions about adult learning, it can be concluded that adult learners have enough abilities and motivations to plan and enact their own learning based on their needs. Therefore, the relationship between adult educators and learners can be conceptualized as a horizontal relationship, and it is important for educators to create effective learning environments that respect learners' needs, autonomy, and individual experiences. Through the learning process, both educators and adult learners' prior knowledge are useful resources for their learning outcomes. Thus, the relationship between adult learners, their experiences, and adult educators is a critical area where meaningful learning occurs.

\section{B. Transformative Learning Theory}

In addition to the foundational theories of Andragogy and self-directed learning that provide the general assumptions of adult learning, transformative learning theory is useful in providing ideal directions for leadership development. Transformative learning aligns with adult learning theory and is also described as the "New Andragogy" (Cranton \& Taylor, 2012). Compared to Andragogy, transformative learning focuses more on explaining learning, while Andragogy focuses more on guiding adult educators (Cranton \& Taylor, 2012).

Philosophical foundations of transformative learning rely on constructivism, humanism, and critical social theory (Cranton \& Taylor, 2012). Mezirow (1991) assumed that "meaning is constructed through our experiences and perceptions of those experiences and future experiences are seen through the lens of the perspectives developed from past experiences" (Canton \& Taylor, 2012, p. 8). For example, people interpret their experiences and make meaning in their own ways, which aligns with constructivism. Humanism stresses the importance of individual human needs based on freedom and autonomy (Cranton \& Taylor, 2012; Merriam \& Bierema, 2014). 
Based on this notion, transformative learning theory values an individual's ability to make personal choices, the potential for unlimited growth and the development of learners, individually defined realities, and all individuals' responsibilities for themselves and others (Elias \& Merriam, 2005). Critical social theory attempts to understand a dominant ideology-"normal" and "natural" ways to think and act that come from our families, communities, and cultures-in different ways by challenging the perspectives we are familiar with (Brookfield, 2005). Thus, transformative learning theory focuses not only on individual changes, but also on social changes. All three philosophical orientations are rooted in transformative learning theory.

Jack Mezirow, who initially conceptualized transformative learning theory, defines transformative learning as the transformation of learners' meaning perspectives (Mezirow, 2006). While Mezirow's theory has become "an internationally well-known and recognized contribution to the understanding of what may be perceived as the most advanced kind of human learning" (Illeris, 2014, p. 149), some scholars have criticized Mezirow's idea for focusing too much on the cognitive dimension of learning as well as how it overlooks unconsciousness in learning (Dirkx, 2012). Michael Newman (2012) also claimed that "many of the case studies that appear in transformative learning in practice are simply examples of good adult education practice" (Newman, 2012, p. 45). In response to these criticisms, transformative learning theory has expanded to include emotional and unconscious dimensions, and critical perspectives in learning.

\section{Mezirow's Transformative Learning Theory}

Mezirow (2012) described making meaning as a learning process, and that transformative learning adds a fifth level to Bruner's (1996) four modes of making meaning. The fifth level of Bruner's model is defined as "becoming critically aware of one's own tacit assumptions and expectations and those of others and assessing their relevance for making an interpretation" (Mezirow, 2012, p. 73). Under the framework of Kitcherner's (1983) three levels of cognitive processing, transformative learning involves the third level of epistemic cognition, which is "how humans monitor their problem solving when engaged in ill-structured problems, reflection on the limits of knowledge, the certainty of knowledge, and the criteria for knowing" (p. 230). Transformative learning theory centers on understanding the ways people learn to negotiate and act on their own goals, values, emotions, and meanings beyond uncritically adopting existing strategies established by others (Mezirow, 2012). Hence, these learning experiences can facilitate an increase of agency in learners' lives and enable them to think critically about both themselves and societies.

To understand Mezirow's theory, it is necessary to explore some of its core concepts. Taking from Habermas (1984), Mezirow categorized two domains of learning: instrumental learning and communicative learning. Instrumental learning refers to "learning to control and manipulate the environment or other people" and communicative learning refers to "learning what others mean when they communicate with you and this involves feelings, intentions, values, and moral issues" (Mezirow, 2012, p. 77). Communicative learning requires critical evaluation of the assumptions of the person communicating, which includes the meaning behind their words, such as authenticity of the person's feeling, truthfulness and qualification of the speaker, and coherence and appropriateness of what is communicated (Mezirow, 2012). Thus, instrumental learning is about more technical knowledge as it relates to task-oriented performance, and communicative learning is about practical knowledge acquired from subinteractive views and reflections on ourselves and others (Mezirow, 1991).

Regarding meaning structures, Mezirow (2012) suggested a frame of reference, which can be described as a "meaning perspective-the structure of assumptions and expectations through which we filter sense impressions" (p. 82). Mezirow (2012) divided this frame of reference into two components: "a habit of mind (a set of assumptions)-broad, generalized, orienting predispositions - and resulting a point of view (an expressed one of a habit of mind)-clusters of meaning schemes, such as immediate specific expectations, beliefs, feelings, attitudes, and judgements" (p. 83). Transformative learning occurs when a frame of reference is transformed in habit of mind or point of view. In this process, transformation is defined as a movement through restructuring and reinterpreting meanings embedded in dominant narratives (Mezirow, 2012).

When learners think outside the box, they need to 
"redefine a problem and reexamine their own assumptions about the content or process for problem solving" (Wang $\&$ Cranton, 2013, p. 28). Transformations usually start with a disorienting dilemma (Mezirow, 2000, p. 22), a challenge derived from an event or experience that does not match with one's pre-existing meaning structure. At the point when transformation is to occur, learners need to explore new ways to deal with the issue, set a plan, act, and learn from their experiences (Wang \& Cranton, 2013). In this process, learners critically reflect on their assumptions and use their frames of reference to solve the problems (Wang \& Cranton, 2013). In transformative learning processes, Mezirow underscored the importance of reflective discourse. Discourse in transformative learning theory is defined as using dialogue to pursue a "common understanding and assessment of the justification of an interpretation or belief" (Mezirow, 2012, p. 78). According to Mezirow, reflective discourse also requires an alignment of emotional maturity with Goleman's (1998) emotional intelligence, such as awareness of one's own emotions, empathy with others' emotions, and controlling one's own emotions.

\section{Principal Leadership Development}

Under the challenges of school reform and increased accountability, school principals are expected to improve schools and support communities as leaders. To be successful, principals must "take on a diverse set of roles, supporting both themselves and teachers who have differing needs, developmental orientations, and preferences" (Drago-Severson, 2009, p. 17). School principals have to continuously develop their leadership skills in order to make the right decisions for organizational goals and support teachers' development in their buildings in and effectively respond to complexity in todays' educational environment. From the standpoint of adult learning theories, school principals can be understood as both adult educator and adult learner.

\section{A. School Principal as Adult Educator}

An adult educator is defined as a person who is responsible for supporting and helping adult learning. As adult educators, there are three dimensions to the roles of school principals (Knowles, Holton \& Swanson, 2005; Park, 2010). First, principals directly work with teachers and staff in the context of leadership. Principals, as adult educators, diagnose school members' specific learning needs and coordinate learning programs to meet those needs. During the learning processes, principals continuously motivate adult learners in their schools by providing effective methodologies and resources and, in turn, help learners evaluate their own learning experiences. Second, school principals are responsible for managing and supporting adult learning programs. In-service trainings at the school level have become an important approach for professional development. As a result, school principals are required to plan and design professional development programs in their schools by matching development programs with the local context. Based on the examination of school contexts and members, school principals plan and operate training programs to achieve the school's organizational goals. Principals also consider the individual needs of their school members and how their personal goals can be achieved via organizational goals when planning these programs. Third, school principals themselves are experienced professionalleaders. They already have accumulated skills and knowledge in their professional areas and, as such, can be models for adult learners (Knowles, Holton \& Swanson, 2005). With experiences in teaching and learning, professional development, and organizational management, school principals can guide adult learners in becoming educational leaders as well.

Aligning with the role of school principal as adult educator, research on learning-centered leadership has highlighted the role of principals in fostering teacher learning (Liu, Hallinger, \& Feng, 2016). Beyond managerial roles, school principals' learning-centered leadership focuses on supporting both teacher development and student learning (Liu, Hallinger, \& Feng, 2016). Researchers have noted that learning-centered leaders are responsible for creating supportive school climates for learning (Heck \& Hallinger, 2014), sharing their own experiences with teachers and staff (Robinson, Lloyd, \& Rowe, 2008), helping teachers identify developmental needs and providing resources for teachers' learning (Vanblaere \& Debvos, 2016).

As our societies become more knowledge driven, school 
is expected to function as a place to create new knowledge and support learning. As educational leaders, school principals promote the building capacities of school members by interacting with teachers, administrators, and other resources. Within their school organizations, they are responsible for supporting the growth of adults as they pursue organizational and personal goals.

\section{B. School Principal as Adult Learner}

In education today, diverse stakeholders require school systems to meet their diverse demands. This complexity of interests from different groups challenges principal leadership to effectively respond to and solve these complicated problems (Wiseman, 2005). As such, school principals are expected to continuously develop their own leadership skills as adult learners.

Researchers have shown the importance of learning for developing school principals' leadership. In a comparative international case study, Ylimaki \& Jacobson (2013) analyzed school principal preparation programs in seven countries in the areas of accountability, decentralization, and demographic change. Ylimaki \& Jacobson (2013) found several features of successful principals responding to these environmental needs, in the context of organizational learning, instructional leadership, and culturally responsive pedagogy. Regarding organizational learning, which can be characterized as capacity building and individual development for school organizational changes (Day and Leithwood, 2007), successful principals understood organizational dynamics and structures and knew how their behaviors and thoughts enabled organizational learning. Instructional leadership, was considered as a critical factor in determining high achievement (Murphy \& Hallinger, 1992), and recently has been expanded to views including distributed leadership and democratic ways of leadership. In this are successful principals had passions for continuous learning and participated in informal and formal leadership development programs. Moreover, they tried to improve democratic principles in both school management and student learning. Regarding culturally responsive pedagogy, which focuses on incorporating students' historical and cultural knowledge from their own backgrounds in school education, principals' leadership with a focus on diversity can assist with responses to different stakeholders from diverse cultural backgrounds.

In their discussion, the authors suggested that principal preparation programs should provide field experiences to cultivate organizational learning, improve instructional leadership, and support culturally responsive pedagogy (Ylimaki \& Jacobson, 2013). School principals have to learn in order to meet the needs of the diverse and individual contexts of their schooling, as well as the global context of educational changes. While principal preparation programs in the seven countries varied in terms of the levels of formality and centrality, effective preparation programs included experience-based learning and systemic support for practice.

Unlike learning in childhood, adult learning relies more on learners' experiences and specific goals. As educational practitioners, principals attain new skills and improve their knowledge on a daily basis, and analyze these experiences as reflective learners. In complicated daily decision making contexts, principals try to negotiate competing values and adopt the most effective strategies based on their theoretical and practical learning experiences (Drago-Severson, 2009). Research on principals' learning indicates the importance of principals' reflection for all school members (Donaldson, 2008; Leithwood \& Jantzi, 1998). When school principals have enough time and resources to share their experiences with fellow principals, they benefit from shared leadership practices when reflecting on their experiences (Kegan \& Lahey, 2009). Osterman and Kottkamp (2004) suggest that reflective practice is important in developing abilities and insights about the nature and influence of leadership. Providing ongoing opportunities to reflect on their own and others' leadership experiences can help school principals gain new wisdom with respect to their practices (Boyatzis \& McKee, 2005; Donaldson, 2008).

When school principals as adult learners re-examine existing assumptions and belief systems, principals can transform their practice and make improvements in their schooling (Drago-Severson, 2009, 2012). It is important for principal leadership development to connect learning to performance in the actual school situation. To support meaningful learning, principal leadership development should be grounded in the interpretation of experiences, which is adaptive to their leadership actions. 


\section{Conceptual Model for Principal Leadership Development}

Based on analysis in earlier chapters, we developed conceptual model for principal leadership development. In this model, we provide three philosophical foundations and suggest goals and strategical directions for principal leadership development programs.

\section{A. Philosophical Foundations}

The philosophical foundations for principal leadership development should rely on the traits of adult learners and goals of adult educators. Table 1 shows the philosophical foundations of transformative learning theory-constructivism, humanism, and critical social theory - for the traits of adult learners and the goals of adult educators.

As noted in Table 1, from the perspective of constructivism, school principals are learners who reconstruct experiences and, at the same time, have goals for reinterpreting their own learning experiences. Therefore, leadership development should build competencies for reinterpreting experiences as well as opportunities to learn based on these experiences. From the perspective of humanism, principals have individual needs and motivations to learn as adult learners; as adult educators, they have to meet the needs of teachers (adult learners as well) by motivating teachers in their schools to learn. This means that school principal leadership development should hone leadership skills to facilitate teachers' learning through the experiences of satisfying (meeting) their needs to learn. Finally, in critical social theory, school principals need to pursue educational innovations and changes by taking account of requirements from diverse stakeholders and interest groups. Thus, principals have to learn how to react to educational accountability and social changes appropriately, as well as how to change schools and teachers throughout their own leadership development.

Based on these philosophical foundations, a conceptual model for educational leadership development was created (see Figure 1).

Reflecting on the features of adult learners and adult educators, principal leadership development is described via four paradigms. Leadership development encourages principals to learn by reconstructing experiences and, at the same time, supports principals in achieving the skills of planning, managing, and evaluating programs for training teachers in their schools. This means, principals who have experienced leadership development program should reinterpret diverse experiences into their own school contexts. In addition, leadership programs must equip principals with competencies to apply what they have learned to their actual school situations, as well

Table 1. Philosophical Foundations for Principal Leadership Development Model

\begin{tabular}{ccc}
\hline Features of Adult Learners & Philosophical Foundations & Goals of Adult Educators \\
\hline Reconstructing experiences & Constructivism & Reinterpreting experiences \\
Needs/Motivations (individual) & Humanism & Meeting (individual) needs \\
Making changes (social/institutional) & Critical social theory & Achieving (social/institutional) goals \\
\hline
\end{tabular}

\begin{tabular}{|c|c|c|c|}
\hline \multirow{4}{*}{ Adult Learner } & \multicolumn{2}{|c|}{ Experience } & \multirow{4}{*}{ Adult Educator } \\
\hline & (Re) Construct & $(\mathrm{Re})$ Interpret & \\
\hline & $\begin{array}{l}\text { Self-directed } \\
\text { Learning }\end{array}$ & $\begin{array}{l}\text { Practice Oriented } \\
\text { Performance }\end{array}$ & \\
\hline & \multicolumn{2}{|c|}{ Learning } & \\
\hline
\end{tabular}

Fig. 1. Paradigms of Principal Leadership Development 
as provide self-directed learning opportunities in relation to individual and social needs. Through the processes of learning, school principals will utilize professional leadership, which assists in making the right decisions for selecting effective methodologies and skills to diagnose and foster teacher learning and growth.

\section{B. Ultimate Goals and Strategical Directions}

Setting goals and directions is an effective way to implement a conceptual model. The goals of school principal leadership development based on adult learning theory include enhancing knowledgeable, practicing, and reflexive leadership. The ultimate purpose of principal leadership is to develop the competencies of planning, analyzing, designing, practicing, evaluating, and improving programs that support school innovation and teacher development in actual school settings.

In relation to this purpose, developing principals as knowledgeable leaders is important. Principals as adult learners should have professional leadership competencies for guiding teachers as adult learners, and consider what teachers want to know and what they should do. This relies on the knowledge principals earned as both adult learners and adult educators. The knowledge attained as an adult educator especially helps principals to recognize problems within their schools and teachers, diagnose causes and needs, and plan and operate appropriate programs. Therefore, principal leadership is a useful resource for developing and managing effective programs for teachers' learning. Another goal of principal leadership development is to encourage school principals as aspiring, practicing leaders. As adult educators, principals need to facilitate teachers' development and organizational growth based on knowledge from their own learning experiences. Lastly, school principals need to have reflexive leadership, which means responding to problems with insights and wisdom by reflecting on their own experiences. In our fast changing school environments, reflexive leadership is critical to overcoming the challenges associated with school accountability.

In this study, we identified four directions for school principal leadership development programs grounded in adult learning theories: systematic training, experientiallead training, individualized training, and practice-based training. It can be seen in the conceptual model presented in Figure 1 that experiences and learning interact with each other. In this context, principals can construct their own knowledge by interpreting their own experiences. Through this process, they assume their roles of adult learners as well as adult educators. To support authentic learning in leadership development, systematic training based on experiences and individual needs is important to connect leadership training and practice.

Systematic training is a series of curriculum development strategies, which includes input, process, output, and feedback. Systematic training is the most important prerequisite for practicing adult learning. The input stage includes recruiting relevant candidates such as school principals or people who plan to become principals who have clear needs and motivations to learn. In the process stage, leadership programs operate using the three directions mentioned above - experience-based training, individualized training, and practice-based training. The last stage of output evaluates outcomes of leadership training. These outcomes are understood as impacts of school improvement, which include not only student achievement, but also overall organizational growth. Principal leadership is one of the factors affecting student achievement because it impacts teacher classroom instruction. Feedback is an analysis of program output, which functions as a window for overall program improvements. The feedback stage, must incorporate meaningful approaches with diverse perspectives to utilize evidence beyond short-term evaluation or simplified self-reported data. Experiential-lead training suggests a focus on reconstruction based on experiences. The existing curriculum for leadership training typically addresses the main aspects of law, finance, leadership theory, and successful cases, but it is limited to connect the leadership training and principals' leadership actions in individual school contexts. Leadership training programs should be rebuilt using an experiential-lead focus. The philosophy and methodology of experiential programming engages principals in direct experiences and focused reflection in order to increase knowledge, develop skills, and clarify values. Individualized training recognizes the need for leadership learning to be designed for the specific needs of individual principals through devices such as mentoring, coaching and consulting. Leadership training is expected to meet the demands of increasing diversity in principal population and student bodies. From this approach, principals can be self-directed and active learners with 
high motivation to develop their leadership skills in order to effectively respond to their school environments.

Practice-based training is forged from authentic issues facing school practice such as closing schools, student dropout rates, and standardized testing. Principal knowledge and skills need to be addressed in the context of these problems and opportunities. In other words, situated learning needs to be highlighted. In principals' daily work, having adaptive leadership skills supported by leadership theories and empirical research is important to solve existing problems and make effective decisions. From this perspective, learning by using actual cases is fruitful for leadership development.

\section{Conclusion}

Over the past half-century, interest in school principal leadership has grown. Much of this growth is attributed to the widespread belief that the quality of school principal leadership makes a significant difference in school effectiveness (Drago-Severson, 2012; Hallinger \& Heck, 2010; Heck \& Hallinger, 2009). In response, international research - including that being done in Korea - continues to accumulate empirical evidence that supports the assumption that school principal leadership has a significant impact on school outcomes (Kang \& Kang, 2006; Shin, 2002; Hallinger \& Heck, 1996; Leithwood et al., 2004). Although there is a global turn toward principal leadership training and scholarly endeavors in the area of principal leadership education have increased in frequency, there have been ongoing debates about conceptual and methodological problems. Many countries, including Korea, have undertaken several efforts to solve these problems. Among the more recent efforts, adult learning theories have been used to shed a light on understanding principal leadership development by emphasizing the importance of learning as adult leaders (Drago-Severson, 2009, 2012). In Korea especially, existing principal leadership programs have been criticized in that: (a) they rely on one-dimensional learning approaches, (b) the programs are not closely connected to actual leadership practices, and (c) they lack opportunities for participants to reflect on their own experiences and decision making (Jin, Lee, Kim, \& Yu,
2003). We suggest that one way to overcome these problems is by forming principal leadership development programs based on adult learning theories. By elaborating on the philosophical foundations, goals, and directions of adult learning theories, we developed a conceptual framework of principal leadership development programs to use in order to support school principals' successful leadership practice.

The conceptual model developed in this study can be used to provide recommendations for principals' action. As Mezirow's transformative learning suggested, adult learners construct knowledge by interacting with their own needs and reflecting upon their own experiences. Furthermore, transformative learning motivates learners to change their views on themselves, others, and the world (Meriam \& Bierema, 2014; Mezirow, 2012). When these learning experiences are connected to leadership performances, school principals improve their leadership skills, which in turn, affects school organizational changes. Thus, school principals can become change agents.

When school principals act as adult learners, they need to be motivated to learn actively in order to develop their leadership skills. Even though there may be environmental stimulus which triggers disorienting dilemmas, what makes authentic learning is learners' own efforts to learn. For this, school principals should consider themselves as life-long learners and have growth mindsets, which lead to belief in the possibility of continuous growth. Moreover, school principals need to have a sensitivity in diagnosing their learning styles, understating strength and weakness of their leadership styles, and identifying challenges in their school organizations (Drago-Severson, 2009). With this sensitivity, principals need to be critical to think of themselves and educational environments as learners. Sharing their experiences in relation to what difficulties and dilemmas they experienced, how they solved these problems, and what helped to develop their leadership strategies. Exchanging experiences with other school principals will help them to revisit their own assumptions and theories in leadership development, which provides more opportunities to learn from both themselves and others.

In the context of school principals as adult educators, it is important for them to understand and value diversity in their teachers' personalities, learning styles, and developmental stages (Drago-Severson, 2012; Kegan \& Lahey, 2009). From this, school leaders have to carefully 
identify their organizational capacities and school organizational goals. School principals should facilitate teachers transformative learning by shaping supportive learning environments. Providing guidance for teachers to recognize what challenges they face and how they can develop strategies to overcome these challenges will be helpful. Depending on individual characteristics, principals can support teachers individually as well as provide appropriate resources at the organizational level. In addition, principals themselves can be useful resources for supporting teachers and organizational learning, because school principals as adult learners can become models in their school buildings. How principals think, learn, and behave has critical impacts on teachers' thoughts and actions in learning and developing leadership. Therefore, principals' learning experiences are connected to school organizational capacities through their leadership actions.

To realize the conceptual framework presented in this paper, leadership development programs should be redesigned and reimagined instead of simply patched up. While our research offers implications for conceptual foundations of principal leadership development, further research should work toward linking our framework to empirical evidence and practical actions in local contexts. This study also did not include any examinations of other contextual factors shaping principal leadership, like politics, economics, sociocultural, and historical factors of nations and society. However, principal leadership is under the influence of these contextual factors. Thus, further research may try to take context specific approaches in developing leadership for school principals.

Increasing pressures from accountability policies have forced schools to become learning centered (DarlingHammond, LaPointe, Meyerson, Orr, \& Cohen, 2007). In addition, increasing diversity in student bodies and educational stakeholders requires effective leadership skills in todays' schooling (Ylimaki \& Jacobson, 2013). In this vein, educational leadership, especially for school principals, should be similarly "learning-centered" in order to deal with this growing complexity (Liu, Hallinger, Feng, 2016). While existing research has focused on principals as leaders, educators, and supporters for learning in their schools, our study is significant in that we provide understandings of how principals' own learning as adult learners mutually interacts with their leadership roles as adult educators. We believe our conceptual framework can provide insights to support this process of leadership development.

\section{References}

Boyatzis, R., \& McKee, A. (2005). Resonantleadership. Boston, MA: Harvard BusinessS chool.

Brookfield, S. D. (2005). The power of critical theory. San Francisco, CA: Jossey-Bass.

Bush, T. (2013). Preparing headteachers in England: Professional certification, not academic learning. Educational Management Administration \& Leadership, 41(4), 453-465.

Cho, Y., \& Joo, H. (2009). Review of educational leadership preparation programs in Korean higher education: examination from the US perspective. Korean Journal of Comparative Education, 19(2), 51-78.

Cranton, P. \& Taylor, E. (2012). Transformative learning theory: Seeking a more unified theory. In Taylor, E. W., \& Cranton, P. (Eds.), The handbook of transformative learning: Theory, research, and practice (pp. 3-20). San Francisco, CA: Jossey-Bass.

Desjardins, F., \& Donaldson Jr, G. A. (2008). High school achievement in Maine: Where you come from matters more than school size and expenditures. Maine Policy Review, 17(1), 84-93.

Dirkx, J. (2012). Nurturing Soul Work: A Jungian approach to transformative learning. In Taylor, E. W., \& Cranton, P. (Eds.), The handbook of transformative learning: Theory, research, and practice (pp.116-130). San Francisco, CA: Jossey-Bass.

Donaldson, G. A. (2008). How leaders learn: Cultivating capacities for school improvement. New York: Teachers College Press.

Drago-Severson, E. E., \& Pinto, K. C. (2009). School leadership in support of teachers' learning: The dramatic differences that financial resources make. Leadership and Policy in Schools, 8(4), 446-476.

Drago-Severson, E. (2009). Leading adult learning: Supporting adult development in our schools. Thousand Oaks, CA: Corwin Press.

Drago-Severson, E. (2012). New opportunities for principal leadership: Shaping school climates for enhanced teacher development. Teachers College Record, 114(3), 1-44.

Hallinger P. (1992). Changing norms of principal 
leadership in the United State. Journal of Educational Administration, 30(3), 35-48.

Hallinger, P., \& Heck, R. (1996). Reassessing the principal's role in school effectiveness: A review of empirical research, 1980-1995. Educational Administration Quarterly, 32(1), 5-44.

Hallinger, P., \& Heck, R. H. (2010). Collaborative leadership and school improvement: Understanding the impact on school capacity and student learning. School Leadership and Management, 30(2), 95-110.

Heck, R. H., \& Hallinger, P. (2009). Assessing the contribution of distributed leadership to school improvement and growth in math achievement. American Educational Research Journal, 46(3), 659689.

Heck, R. H., \& Hallinger, P. (2014). Modeling the longitudinal effects of school leadership on teaching and learning. Journal of Educational Administration, 52(5), 653-681.

Illeris, K. (2014). Transformative learning and identity. Journal of Transformative Education, 12(2), 148-163.

Jin, D., Kim, B., Lee, Y., \& Yu., H (2003). A study on the leadership development program for principals: A constructivist leadership development program for conflict-management between principals and union teachers. The Journal of Korean Teacher Education, 20(3), 117-138.

Kang, K. \& Kang, K. (2006). A study on the relationship among principals' transformational leadership, teacher's followership, and school organizational effectiveness. The Journal of Educational Administration, 24(4), 239-262.

Kegan, R., \& Lahey, L. L. (2009). Immunity to change: How to overcome it and unlock the potential in yourself and your organization. Boston, MA: Harvard Business School Press.

Knowles, M. S. (1975). Self-directed learning: A guide for learners and teachers. New York: Association Free Press.

Knowles, M. S. (1980). The modern practice of adult education: From pedagogy to andragogy (2nd ed.). New York: Cambridge.

Leithwood, K., \& Jantzi, D. (1998, April). Distributed leadership and student engagement in school. Paper Presented at the annual meeting of the American Educational Research Association, San Diego, CA.

Leithwood, K., Louis, K., Anderson, S. and Wahlsttom, K. (2004). Review of research: How leadership influences student learning. Retrieved from http:// www.wallacefoundation.org/knowledge-center/Docu ments/How-Leadership-Influences-Student-Learning. pdf.

Liu, S., Hallinger, P., \& Feng, D. (2016). Supporting the professional learning of teachers in China: Does principal leadership make a difference? Teaching and Teacher Education, 59, 79-91.

Merriam, S. B., \& Bierema, L. L. (2014). Adult learning: Linking theory and practice. San Francisco, CA: Jossey-Bass.

Mezirow, J. (1991). Transformative dimensions of adult learning. San Francisco: Jossy-Bass

Mezirow, J. (2012). Learning to think like an adult. In Taylor, E. W., \& Cranton, P. (Eds), The handbook of transformative learning: Theory, research, and practice (pp. 73-95). San Francisco, CA: Jossey-Bass.

Mezirow, J., Taylor, E. W., \& Associates (2009). Transformative learning in practice. San Francisco, CA: Jossey-Bass.

Murphy, J. (1990). The reform of school administration: Pressures and calls for change. In J. Murphy (Ed.), The reform of American public education in the 1980s: Themes and cases (pp.277-304). Berkeley, CA: McCutchan.

Osterman, K. F., \& Kottkamp, R. B. (2004). Reflective practice for educators: Professional development to improve student learning. Thousand Oaks, CA: Corwin Press.

Park, R. (2010). The effect of a school principal's leadership in adult education, the school's organizational culture, and teacher's learning culture on the organizational effectiveness. Soongsil University Dissertation.

Piaget, J. (2000). Piaget's theory of cognitive development. In Lee, K. (Ed.), Childhood cognitive development: The essential readings (pp. 33-47). Malden, MA: Wiley-Blackwell.

Robinson, V. M., Lloyd, C. A., \& Rowe, K. J. (2008). The impact of leadership on student outcomes: An analysis of the differential effects of leadership types. Educational administration quarterly, 44(5), 635-674.

Savicevic, D. (2008). Convergence or divergence of ideas on andragogy in different countries. International Journal of Lifelong Education, 27(4), 361-378.

Shin, J. (2002). A study on the relations among teachers' perceived school principals' transformational leadership, school organizational culture and school organizational effectiveness. The Journal of Educational Administration, 20(3), 91-115.

Vanblaere, B., \& Devos, G. (2016). Exploring the link between experienced teachers' learning outcomes and individual and professional learning community characteristics. School Effectiveness and School Improvement, 27(2), 205-227. 
Wang, V. C., \& Cranton, P. (2013). Transformative learning and technological applications in adult and vocational education. International Journal of Information and Communication Technology Education, 9(1),
26-37.

Wiseman, A. W. (2005). Principals under pressure: the growing crisis. Lanham: MD: Scarecrow Education. 